\section{(A) Check for updates}

Cite this: Dalton Trans., 2019, 48 , 9818

Received 5th April 2019

Accepted 15th May 2019

DOI: $10.1039 / c 9 d t 01448 a$

rsc.li/dalton

\title{
Improving the efficiency of copper-dye-sensitized solar cells by manipulating the electrolyte solution
}

\author{
Alessia Colombo, (DD a,b Claudia Dragonetti, (D) *a,b Francesco Fagnani, ${ }^{a}$ \\ Dominique Roberto, (D) ${ }^{a, b}$ Fabio Melchiorre ${ }^{c}$ and Paolo Biagini ${ }^{c}$
}

\begin{abstract}
The use of a copper(I) dye, bearing a 2,9-dimesityl-1,10-phenanthroline and a 6,6'-dimethyl-2,2'-bipyridine-4,4'-dibenzoic acid, was investigated in DSSCs with various electrolyte solutions based on two different redox mediators, namely the common $\mathrm{I}^{-} / \mathrm{I}_{3}^{-}$couple and an interesting copper electron shuttle. The experimental results provide evidence of the importance of the redox mediator concentration and the crucial role of additives such as 4-tert-butylpyridine and lithium bis(trifluoromethanesulfonyl)imide in the performance of sustainable "full-copper" DSSCs, consolidating the way to DSSCs with Earth-abundant components.
\end{abstract}

\section{Introduction}

Since the discovery of Grätzel-type dye-sensitized solar cells (DSSCs) as a convenient way for the conversion of solar energy to electrical energy, ${ }^{1}$ there has been a phenomenal amount of work to improve their photoconversion efficiency $(\eta) .^{2}$ In particular, a lot of effort has been devoted to optimize the sensitizer $^{3-8}$ and the redox mediators. ${ }^{8-13}$ Except for a few organic or zinc(II) porphyrin-sensitized solar cells which reach up to $14 \%$ efficiency, ${ }^{14-16}$ the best photovoltaic performances (ca. 11\% efficiencies) have so far been achieved with ruthenium complexes such as cis-di(thiocyanato)bis(2,2'-bipyridine4,4'-dicarboxylate) $\mathrm{Ru}(\mathrm{II})$ and the related doubly deprotonated complex $(\mathbf{N} 719)^{17}$ with the iodide/triiodide couple $\left(\mathrm{I}^{-} / \mathrm{I}_{3}{ }^{-}\right)$as the electrolyte. ${ }^{18,19}$ Cyclometalated ruthenium complexes represent good alternatives for application in DSSCs, due to their higher stability. ${ }^{20-28}$ However, a drawback of these sensitizers is the scarcity of ruthenium in the Earth's crust and its high cost. For this reason, in the last few years, an exponential amount of work has been dedicated to the use of dyes based on Earth abundant metals such as environmentally-friendly copper(I) complexes in combination with the $\mathrm{I}^{-} / \mathrm{I}_{3}{ }^{-}$redox mediator. $^{6-8,29-39}$ Their photoconversion efficiencies are still lower than the values obtained for state-of-the-art ruthenium(II) dyes, but it is important to point out that the dye structures and dye/electrolyte combinations in the ruthenium-based

\footnotetext{
${ }^{a}$ Dipartimento di Chimica dell'Università degli Studi di Milano, UdR-INSTM, via Golgi 19, I-20133 Milano, Italy.E-mail: claudia.dragonetti@unimi.it ${ }^{b}$ ISTM-CNR and SmartMatLab dell'Università degli Studi di Milano, via Golgi 19, I-20133 Milano, Italy

${ }^{c}$ Research Center for Renewable Energy \& Enviromental Istituto Donegani, Eni S.p.A., via Fauser 4, I-28100 Novara, Italy. E-mail: paolo.biagini@eni.com
}

DSSCs have been optimized for almost 30 years, whereas copper-based DSSCs are still in their infancy and, with systematic tuning of the dye and electrolyte components ${ }^{6-8,35-37}$ and with the use of co-sensitization, ${ }^{38}$ enhanced performances are progressively being attained.

The actual $4.66 \%$ record efficiency, corresponding to a remarkable $63 \%$ relative efficiency $\left(\eta_{\text {rel }}\right)^{40}$ with respect to a N719-sensitized control cell set at $100 \%$, was obtained with a copper(I) complex having as an anchoring ligand a 4,4'-dicarboxylic acid-6,6'dimesityl-2,2'-bipyridine and, as an ancillary ligand, a 4,4'-bis( $N, N$ diethylaminestyryl)-6,6'dimethyl-2,2'bipyridine, using the $\mathrm{I}^{-} / \mathrm{I}_{3}{ }^{-}$redox mediator. ${ }^{39}$ It should be pointed out that this record value was reached with unmasked cells $^{39}$ and therefore could be overestimated. In fact, masking the cells is crucial in order to have accurate values of photoconversion efficiency. ${ }^{41}$

Besides, the long term incompatibility of copper complexes with $\mathrm{I}^{-} / \mathrm{I}_{3}{ }^{-}$, due to the low solubility of $\mathrm{CuI}^{42,43}$ and the problems related to this redox couple, ${ }^{8}$ led to the preparation of iodine-free copper(I) solar cells. The use of $\left[\operatorname{Co}\left(2,2^{\prime}-\right.\right.$ bipyridine $\left.)_{3}\right]^{2+/ 3+}$ as a redox couple was the first important step towards the development of this kind of DSSC. ${ }^{44}$ In parallel, the fact that $\mathrm{Cu}^{+/ 2+}$ mediators can outperform both iodinebased and Co-based electrolytes in combination with various dyes $^{45-50}$ along with the ability of $\mathrm{Cu}$ mediators to solve the thermodynamic and kinetic dichotomies of the device operation $^{51-53}$ were the springboard for the development of "full-copper" DSSCs. ${ }^{54,55}$ A promising photoconversion efficiency (2.06\% corresponding to $38.1 \%$ relative to N719 set at $100 \%$, masked cells ${ }^{41}$ ) was reached with a copper(I) dye, bearing one 4,4'-dimethoxy-6,6'-dimethyl-2,2'-bipyridine and a phosphonic acid anchor, and a copper redox mediator bearing two 4,4'-dimethoxy-6,6'-dimethyl-2,2'-bipyridines. ${ }^{55}$ In parallel, 


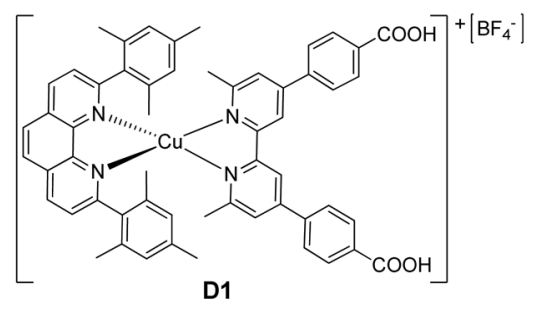

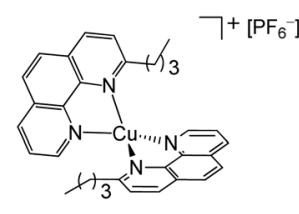

E1

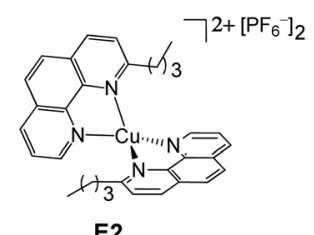

E2
Chart 1 Chemical structures of the investigated dye (D1) and copperbased redox mediators (E1/E2).

we found that the use of a heteroleptic copper dye (D1, Chart 1), bearing one 2,9-dimesityl-1,10-phenanthroline and a 6,6'-dimethyl-2,2'-bipyridine-4,4'-dibenzoic acid anchoring ligand, in combination with a homoleptic copper(I/II) complex bearing two 2-n-butyl-1,10-phenanthrolines (E1/E2, Chart 1) as an electron shuttle, allows a fair photoconversion efficiency (1.4\% corresponding to $16 \% \eta_{\text {rel }}$, masked cells ${ }^{41}$ ) to be reached although lower than that obtained with the conventional $\mathrm{I}^{-} / \mathrm{I}_{3}{ }^{-}$ couple as the electrolyte. ${ }^{54,56}$ These first examples of fullcopper solar cells ${ }^{54,55}$ open a new route for cheap and environmentally friendly DSSCs. Now, effort should be devoted to improve their photoconversion efficiency.

In the present work, we focus our attention on DSSCs based on D1 as a dye and E1/E2 as a redox mediator, investigating the effect of both the electrolyte solution concentration and the addition of 4-tert-butylpyridine and lithium bis(trifluoromethanesulfonyl)imide.

\section{Experimental}

\section{Synthesis of copper complexes}

The dye and the redox mediators were prepared as we previously reported. ${ }^{54}$

\section{Fabrication and evaluation of solar cells}

$\mathrm{TiO}_{2}$ electrodes were prepared by spreading (doctor blading) a colloidal $\mathrm{TiO}_{2}$ paste $(20 \mathrm{~nm}$ sized; "Dyesol" DSL 18NR-T) onto a conducting glass slide (FTO, Hartford glass company, TEC 8, with a thickness of $2.3 \mathrm{~mm}$ and a sheet resistance in the range of 6-9 $\Omega \mathrm{cm}^{-2}$ ) that had been cleaned with water and EtOH, treated with a plasma cleaner at $100 \mathrm{~W}$ for $10 \mathrm{~min}$, dipped in aqueous $\mathrm{TiCl}_{4}$ solution $\left(4.5 \times 10^{-2} \mathrm{M}\right)$, at $70{ }^{\circ} \mathrm{C}$, for $30 \mathrm{~min}$, and washed with ethanol. After the first drying at $125{ }^{\circ} \mathrm{C}$ for $15 \mathrm{~min}$, a reflecting scattering layer containing $>100 \mathrm{~nm}$ sized $\mathrm{TiO}_{2}$ ("Solaronix" Ti-Nanoxide R/SP) was bladed over the first $\mathrm{TiO}_{2}$ coat and sintered until $500{ }^{\circ} \mathrm{C}$ for $30 \mathrm{~min}$. Then the glass coated $\mathrm{TiO}_{2}$ was dipped again into a freshly prepared aqueous
$\mathrm{TiCl}_{4}$ solution $\left(4.5 \times 10^{-2} \mathrm{M}\right)$, at $70{ }^{\circ} \mathrm{C}$ for $30 \mathrm{~min}$, washed with ethanol and heated once more at $500{ }^{\circ} \mathrm{C}$ for $15 \mathrm{~min}$. At the end of this operation, the final thickness of the $\mathrm{TiO}_{2}$ electrode was in the range of $8-12 \mu \mathrm{m}$, as determined by SEM analysis. After the second sintering, the FTO glass coated $\mathrm{TiO}_{2}$ was cooled at about $80^{\circ} \mathrm{C}$ and immediately dipped into a methanol solution $\left(1.5 \times 10^{-3} \mathrm{M}\right.$, previously prepared and maintained in a dry $\mathrm{N}_{2}$ atmosphere) of the dye at room temperature for $24 \mathrm{~h}$. The dyed titania-glasses were washed with EtOH and dried at room temperature under an $\mathrm{N}_{2}$ flux. Finally, the excess of $\mathrm{TiO}_{2}$ was removed with a sharp Teflon penknife. A $50 \mu \mathrm{m}$ thick Surlyn spacer (TPS 065093-50 from Dyesol) was used to seal the photoanode and the platinized FTO counter electrode. Then the cell was filled up with the desired electrolyte solution (see the details reported in Table 1). The photovoltaic performance

Table 1 Main PV parameters of DSSCs based on the copper dye D1 (in the presence of a $4 \times 4 \mathrm{~mm}^{2}$ square opening black mask)

\begin{tabular}{|c|c|c|c|c|c|c|c|}
\hline & Dye & Electrolyte & $\begin{array}{l}J_{\mathrm{SC}}, \\
\mathrm{mA} \mathrm{cm}{ }^{-2}\end{array}$ & $\begin{array}{l}V_{\mathrm{OC}}, \\
\mathrm{mV}\end{array}$ & $\mathrm{FF}$ & $\eta, \%$ & $\eta_{\mathrm{rel}}{ }^{a}, \%$ \\
\hline 1 & N719 & $\mathrm{I}^{-} / \mathrm{I}_{3}^{-b}$ & 15.17 & 659 & 68.7 & 6.87 & $100 \%$ \\
\hline 2 & D1 & $\mathrm{I}^{-} / \mathbf{I}_{3}^{-c, d}$ & 6.17 & 670 & 73.9 & 3.05 & $44.4 \%$ \\
\hline 3 & D1 & $\mathrm{I}^{-} / \mathrm{I}_{3}{ }^{-c, e}$ & 6.41 & 648 & 73.0 & 3.03 & $44.1 \%$ \\
\hline 4 & D1 & $\begin{array}{l}0.085 \text { M E1 } \\
0.0085 \text { M E2 } \\
0.05 \text { M LiTFSI }^{f, g}\end{array}$ & 4.06 & 606 & 63.9 & 1.57 & $22.9 \%$ \\
\hline 5 & D1 & $\begin{array}{l}0.085 \mathrm{M} \mathrm{E} 1 \\
0.0085 \mathrm{M} \mathrm{E} 2 \\
0.05 \mathrm{M} \mathrm{LiTFSI} \\
0.14 \mathrm{M} t \text { BuPy }\end{array}$ & 3.69 & 708 & 62.7 & 1.64 & $23.9 \%$ \\
\hline 6 & D1 & $\begin{array}{l}0.038 \mathrm{M} \mathrm{E} 1 \\
0.0038 \mathrm{M} \mathrm{E} 2 \\
0.022 \mathrm{M} \mathrm{LiTFSI}^{f}\end{array}$ & 4.35 & 630 & 63.1 & 1.73 & $25.2 \%$ \\
\hline 7 & D1 & $\begin{array}{l}0.038 \mathrm{M} \mathrm{E} 1 \\
0.0038 \mathrm{M} \mathrm{E} 2 \\
0.022 \mathrm{M} \mathrm{LiTFSI} \\
0.062 \mathrm{M} t \text { BuPy }\end{array}$ & 2.88 & 725 & 59.9 & 1.25 & $18.2 \%$ \\
\hline 8 & D1 & $\begin{array}{l}0.085 \mathrm{M} \mathrm{E} 1 \\
0.0085 \mathrm{M} \mathrm{E}^{2} \\
0.1 \mathrm{M} \mathrm{LiTFSI}^{f} \\
0.28 \mathrm{M} t \text { BuPy }\end{array}$ & 5.77 & 622 & 70.1 & 2.51 & $36.5 \%$ \\
\hline 9 & D1 & $\begin{array}{l}0.038 \mathrm{M} \mathrm{E} 1 \\
0.0038 \mathrm{M} \mathrm{E} 2 \\
0.1 \mathrm{M} \mathrm{LiTFSI} \\
0.28 \mathrm{M} t \text { BuPy }\end{array}$ & 4.98 & 543 & 66.2 & 1.84 & $26.8 \%$ \\
\hline 10 & D1 & $\begin{array}{l}0.085 \mathrm{M} \mathrm{E} 1 \\
0.0085 \mathrm{M} \mathrm{E}^{2} \\
0.1 \mathrm{M} \mathrm{LiTFSI}^{f} \\
0.28 \mathrm{BuPy} \\
0.26 \mathrm{M} \mathrm{MBIPF}_{6}{ }^{h}\end{array}$ & 2.22 & 705 & 56.0 & 0.88 & $12.8 \%$ \\
\hline
\end{tabular}

${ }^{a}$ Relative efficiency with respect to an N719-sensitized control cell set at $100 \% .{ }^{b} 0.6 \mathrm{M} \mathrm{N}$-methyl- $N$-butylimidazolium iodide, $0.03 \mathrm{M}$ iodine, $0.1 \mathrm{M}$ guanidinium thiocyanate, and $0.5 \mathrm{M} t$-BuPy in a $15 / 85(\mathrm{v} / \mathrm{v})$ mixture of valeronitrile/acetonitrile. ${ }^{c} 0.26 \mathrm{M} \mathrm{N}$-methyl- $\mathrm{N}$-butylimidazolium iodide, $0.01 \mathrm{M}$ LiI, $0.017 \mathrm{M}$ iodine, and $0.28 \mathrm{M} t$-BuPy in a 15/85 (v/v) mixture of valeronitrile/acetonitrile. ${ }^{d}$ By working with $0.65 \mathrm{M}$ $N$-methyl- $N$-butylimidazolium iodide, $0.025 \mathrm{M} \mathrm{LiI,} 0.04 \mathrm{M}$ iodine, and $0.28 \mathrm{M} t$-BuPy, the PV parameters are: $J_{\mathrm{SC}}=6.1 \mathrm{~mA} \mathrm{~cm} \mathrm{~cm}^{-2}, V_{\mathrm{OC}}=$ $592 \mathrm{mV}, \mathrm{FF}=71$, and $\eta=2.5 \% .^{56} e^{e} 0.025 \mathrm{M}$ guanidinium iodide is present. ${ }^{f}$ LiTFSI is lithium bis(trifluoromethanesulfonyl)imide; all the electrolyte solutions containing the $\mathbf{E 1 / E 2}$ redox couple are in acetonitrile. ${ }^{g}$ By working with $0.17 \mathrm{M} \mathrm{Cu}(\mathrm{I}), 0.017 \mathrm{M} \mathrm{Cu}(\mathrm{II})$ and $0.1 \mathrm{M}$ LiTFSI in acetonitrile, the $\mathrm{PV}$ parameters are: $J_{\mathrm{SC}}=3.8 \mathrm{~mA} \mathrm{~cm} \mathrm{~cm}^{-2}, V_{\mathrm{OC}}=$ $593 \mathrm{mV}, \mathrm{FF}=61$, and $\eta=1.4 \% .^{56} \mathrm{MBIPF}_{6}$ is $[N$-methyl- $N$ butylimidazolium] $\left[\mathrm{PF}_{6}\right]$. 
of the cells was measured with a solar simulator (Abet 2000) equipped with a $300 \mathrm{~W}$ xenon light source; the light intensity was adjusted with a standard calibrated Si solar cell ("VLSI Standard" SRC-1000-RTD-KG5); the current-voltage characteristics were determined by applying an external voltage to the cell and measuring the generated photocurrent with a "Keithley 2602A" (3A DC, 10A Pulse) digital source meter. For a given complex and configuration, at least four different devices were made and characterized on different days; the difference between the average and the highest or lowest efficiency values was usually lower than 5\%. The PV parameters were calculated taking into account the values of the active areas (generally in the range $13-15 \mathrm{~mm}^{2}$ ) measured by microphotography. In the case of masked devices, a black mask with a $4 \times 4 \mathrm{~mm}^{2}$ square opening, realized with a cutting plotter, was carefully placed over the devices making sure to completely leave the photoanodes uncovered. IPCE measurements were performed in the DC mode in the 300-900 nm region with a Bentham PVE300 instrument equipped with a xenon QTH lamp, a TMc300 monochromator and a Stanford SR830 DSP amplifier.

\section{Results and discussion}

We prepared, with the HETPHEN synthetic method, ${ }^{57}$ the copper(I) dye D1 (Chart 1) bearing one 2,9-dimesityl-1,10-phenanthroline, where the mesityl groups provide enough steric hindrance to avoid the formation of homoleptic complexes and prevent geometric changes on going from $\mathrm{Cu}$ (I) to $\mathrm{Cu}$ (II), ${ }^{58}$ and a 6,6'-dimethyl-2,2'-bipyridine-4,4'-dibenzoic acid, chosen as the anchoring ligand because of its particular ability to anchor the dye on the titania surface. ${ }^{31,54}$ The performance of D1 in DSSCs was investigated with various electrolyte solutions based on two different redox mediators, namely the common $\mathrm{I}^{-} / \mathrm{I}_{3}{ }^{-}$couple and the recently reported copper electron shuttle E1/E2 (Chart 1). ${ }^{54}$

Dye-sensitized solar cells were prepared using FTO glass coated $\mathrm{TiO}_{2}$ sensitized with $\mathbf{D 1}$ as the photoanode, a platinized FTO as the counter electrode and an electrolyte solution containing $\mathrm{I}^{-} / \mathrm{I}_{3}{ }^{-}$or E1/E2 as the redox couple (see Experimental). The results of the investigated fully masked thin film DSSCs are presented in Table 1 together with those obtained with the $\mathrm{Ru}(\mathrm{II})$ benchmark N719. In addition to the absolute photoconversion efficiency $(\eta)$, Table 1 reports the efficiency relative to a cell based on the $\mathbf{N 7 1 9}$ dye and the $\mathrm{I}^{-} / \mathrm{I}_{3}{ }^{-}$electrolyte set at $100 \%\left(\eta_{\text {rel }}\right)$. Fig. 1 shows the current density $v s$. voltage curves of the devices under AM 1.5 simulated solar illumination with a power light intensity of $100 \mathrm{~mW} \mathrm{~cm}^{-2}$.

It turned out that the masked dye-sensitized solar cell, based on $\mathbf{D 1}$ as the dye and containing $\mathrm{I}^{-} / \mathrm{I}_{3}{ }^{-}$as the redox shuttle, has a $3.05 \%$ photo-conversion efficiency (Table 1, entry 2). This performance is remarkable for such a simple dye.

Remarkably, the DSSC based on D1 as the dye and $\mathrm{I}^{-} / \mathrm{I}_{3}{ }^{-}$as the redox shuttle (entry 2) has a photoconversion efficiency much higher than that previously reported by using the same 4-tert-butylpyridine concentration but a 2.5 times more con-

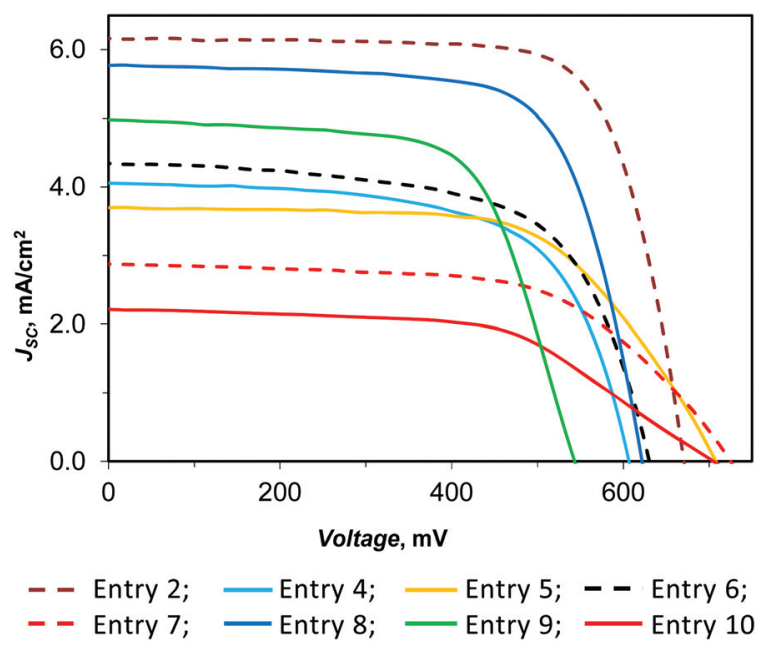

Fig. 1 Current density-voltage characteristics of masked DSSCs in the presence of D1 as the dye and various electrolytes.

centrated electrolyte solution based on the same redox shuttle $\left(\eta=2.5 \% ; \eta_{\text {rel }}=28 \%\right.$, masked cell $),{ }^{56}$ due to an increase of $J_{\mathrm{SC}}$, $V_{\mathrm{OC}}$, and FF. This result is of particular interest, showing that it is possible to improve the DSSC efficiency by simply manipulating the electrolyte solution concentration. Addition of guanidinium iodide doesn't have a significant effect on the photoconversion efficiency since the observed increase of $J_{\mathrm{SC}}$ is perfectly balanced by the corresponding decrease of $V_{\mathrm{OC}}$ (compare entries 2 and 3 ).

These results prompted us to study the effect of the electrolyte solution concentration on "full-copper" DSSCs. We recently reported that substitution of the $\mathrm{I}^{-} / \mathrm{I}_{3}{ }^{-}$redox couple with the E1/E2 couple leads to a lower but still good efficiency $\left(\eta=1.4 \% ; \eta_{\text {rel }}=16 \%\right.$ ), by working with $0.17 \mathrm{M} \mathrm{Cu}(\mathrm{I}), 0.017 \mathrm{M}$ $\mathrm{Cu}(\mathrm{II})$ and $0.1 \mathrm{M}$ LiTFSI in acetonitrile. ${ }^{56}$ In the present work, we found that dilution by a factor of two leads to an enhancement of $J_{\mathrm{SC}}, \mathrm{FF}$ and $V_{\mathrm{OC}}$ affording a higher photo-conversion efficiency (Table 1 , entry $4 ; \eta=1.57 \%, \eta_{\text {rel }}=22.9 \%$ ). Further dilution, up to a factor of 4.5 with respect to the original concentration, leads to an even better performance (entry $6, \eta=$ $1.73 \%, \eta_{\text {rel }}=25.2 \%$ ), due to a simultaneous increase of $J_{\mathrm{SC}}$ and $V_{\text {OC. }}$. The increase of the short-circuit photocurrent observed upon dilution of E1/E2 can be attributed to the less competitive light harvesting of $\mathbf{E} \mathbf{1}\left(\lambda_{\max }=452 \mathrm{~nm}\right.$ (ref. 54)) with the dye D1 $\left(\lambda_{\max }=478 \mathrm{~nm}\right.$ (ref. 54)). IPCE measurements (Fig. 2) supported this interpretation; in fact, devices derived from entry 4 and entry 6 are very similar and differ only in the 400-480 nm region, where in the presence of a more diluted electrolyte, a slightly higher external quantum efficiency was measured accordingly with the corresponding $J_{\mathrm{SC}}$. In both cases, addition of 4-tert-butylpyridine (in a molar ratio 2.8 , with respect to LiTFSI, (entries 5 and 7) produces a significant increase of $V_{\mathrm{OC}}$ (about $100 \mathrm{mV}$ ), but the corresponding lower $J_{\mathrm{SC}}$ and $\mathrm{FF}$ lead to a similar (entry $5, \eta=1.64 \%, \eta_{\text {rel }}=23.9 \%$, to be compared with entry 4 ) or lower (entry $7, \eta=1.25 \%, \eta_{\text {rel }}=18.2 \%$, to be compared with entry 6) efficiency. 


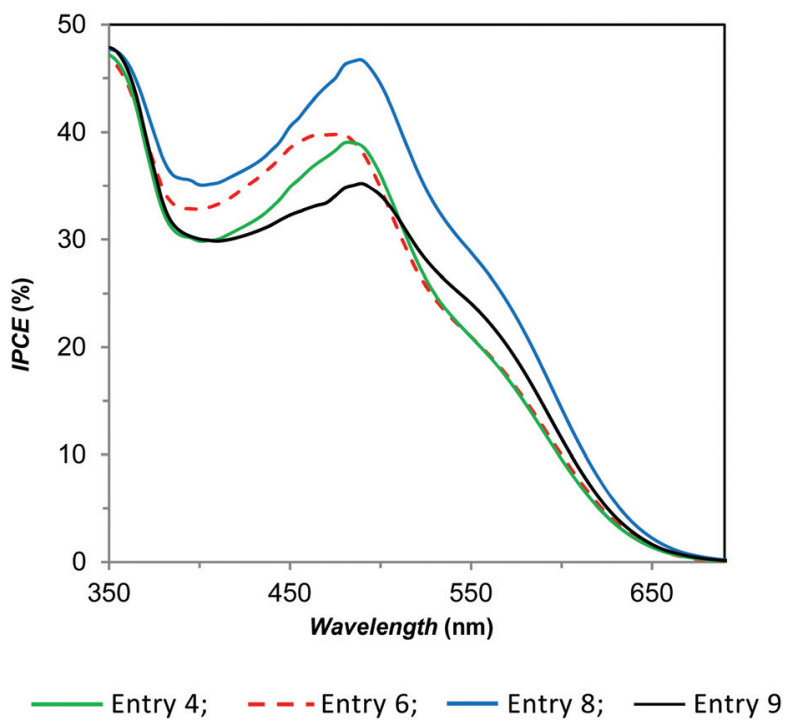

Fig. 2 IPCE characteristics of selected DSSCs in the presence of D1 as the dye and various electrolyte compositions.

However, surprisingly, by keeping the same E1/E2 concentration as in entry 4 and adding LiTFSI and $t$-BuPy, maintaining the $1: 2.8$ molar ratio but with a double concentration, we obtained a significant increase of all the photovoltaic parameters $\left(J_{\mathrm{SC}}, V_{\mathrm{OC}}\right.$, and $\left.\mathrm{FF}\right)$, and in these conditions, a much higher efficiency is reached (entry $8, \eta=2.51 \%, \eta_{\text {rel }}=36.5 \%$ ). We observed the same effect also in the presence of E1/E2 where the concentration decreased by a factor of 2.3 , but with this setting, we recorded an increase only for $J_{\mathrm{SC}}$ and $\mathrm{FF}$, while $V_{\text {OC }}$ decreased by almost $100 \mathrm{mV}$ (entry 9 versus entry 6); consequently, the growth in efficiency was lower compared to entry 8. The corresponding IPCE data, which agree with the current density/voltage measurements, are shown in Fig. 2. Finally, the addition of $[N$-methyl- $N$-butylimidazolium $]\left[\mathrm{PF}_{6}\right]\left(\mathrm{MBIPF}_{6} / \mathbf{E} \mathbf{1}=\right.$ 3 , molar ratio), into our powerful electrolyte solution, produced a noteworthy growth of the $V_{\mathrm{OC}}$, but also an important loss in $J_{\mathrm{SC}}$ and $\mathrm{FF}$, so the efficiency was reduced to about onethird with respect to our best result (entry $10, \eta=0.88 \%, \eta_{\text {rel }}=$ $12.8 \%$ ). This result shows the negative effect of $\mathrm{MBIPF}_{6}$ in the optimization of the electrolyte solution for efficient "fullcopper" DSSCs.

Remarkably, the simultaneous increase of the molar ratio LiTFSI/E1 (in the range 1.2-2.6) and $t$-BuPy/E1 (in the range 3.3-7.4) has a positive effect on the performance of the cell, allowing, to our knowledge, the best absolute efficiency (entry $8, \eta=2.51 \%$ ) reported up to now for a "full-copper" solar cell to be reached. It has been reported that 4-tert-butylpyridine can have a negative effect on the $\mathrm{Cu}$-mediated redox couple bearing bipyridine or phenanthroline ligands with methyl groups adjacent to the nitrogen donor atoms. ${ }^{59-62}$ In fact, contrary to $\mathrm{Cu}(\mathrm{I})$ species, the $\mathrm{Cu}$ (II) counterparts tend to accept 4-tert-butylpyridine as the ligand. It appeared that the so-formed penta-coordinated $\mathrm{Cu}(\mathrm{II})$ species have higher reorganization energies for the charge recombination process, causing lower recombination rates; they shift the electrolyte potentials to more negative values and cause higher diffusion resistances of the $\mathrm{Cu}$ complexes. ${ }^{62}$ In contrast, our results show that the presence of 4-tert-butylpyridine can have a positive influence on the performance of "full-copper" DSSCs. Therefore, future work should be devoted in order to better understand the role of this Lewis base.

\section{Conclusions}

In this work a heteroleptic copper(I) sensitizer bearing one 2,9dimesityl-1,10-phenanthroline and a 6,6'-dimethyl-2,2'-bipyridine-4,4'-dibenzoic acid, D1, was used in DSSCs with the common $\mathrm{I}^{-} / \mathrm{I}_{3}{ }^{-}$redox couple or the copper(I)/copper(II) couple. Very good efficiencies were reached. It appeared that the composition, as well as the molar ratios between the various components of the electrolyte solutions, play a crucial role in the performance of the DSSCs. Upon dilution of the redox shuttle, there is an increase of the short-circuit photocurrent. Such an observation can be attributed to the less competitive light harvesting of the diluted electrolyte with respect to the dye. Manipulation of the electrolyte solution by using an adequate quantity of LiTFSI and tert-butylpyridine allows to improve the performance of "full-copper" DSSCs to be greatly improved. Remarkably, for masked cells based on the same copper(I) dye D1, the best absolute efficiency reached with the copper(I)/ copper(II) redox shuttle $(\eta=2.51 \%)$ is $82 \%$ the best efficiency reached with the problematic $\mathrm{I}^{-} / \mathrm{I}_{3}{ }^{-}$couple $(\eta=3.05 \%)$, confirming the great potential of "full-copper" DSSCs and consolidating the way to DSSCs with Earth-abundant components.

\section{Conflicts of interest}

There are no conflicts to declare.

\section{Acknowledgements}

A. C. thanks the Università degli Studi di Milano (Piano Sostegno alla Ricerca 2015-17-LINEA 2 Azione A - Giovani Ricercatori) for financial support. The "Ministero degli Affari Esteri e della Cooperazione Internazionale" is also acknowledged (bilateral project Italy-India, Prot. nr. MAE0104617) for financial support. Part of this work has been performed under a research contract no. 3500005452 between the University of Milano and Eni S.p.A, Rome, Italy.

\section{Notes and references}

1 B. O'Regan and M. Grätzel, Nature, 1991, 353, 737.

2 G. Boschloo, Front. Chem., 2019, 7, 77.

3 M. Grätzel, Acc. Chem. Res., 2009, 42, 1788.

4 G. C. Vougioukalakis, A. I. Philippopoulos, T. Stergiopoulos and P. Falaras, Coord. Chem. Rev., 2011, 255, 2602.

5 L.-L. Li and E. W.-G. Diau, Chem. Soc. Rev., 2013, 42, 291. 
6 C. E. Housecroft and E. C. Constable, Chem. Soc. Rev., 2015, 44, 8386.

7 M. Sandroni, Y. Pellegrin and F. Odobel, C. R. Chim., 2016, 19, 79.

8 M. Magni, P. Biagini, A. Colombo, C. Dragonetti, D. Roberto and A. Valore, Coord. Chem. Rev., 2016, 322, 69.

9 T. W. Hamann, R. A. Jensen, A. B. F. Martinson, H. Van Ryswykac and J. T. Hupp, Energy Environ. Sci., 2008, 1, 66.

10 T. W. Hamann, Dalton Trans., 2012, 41, 3111.

11 M. Wang, S. M. Graetzel, Zakeeruddin and M. Grätzel, Energy Environ. Sci., 2012, 5, 9394.

12 J. Wu, Z. Lan, J. Lin, M. Huang, Y. Huang, L. Fan and G. Luo, Chem. Rev., 2015, 115, 2136.

13 B. Pashaei, H. Shahroosvand and P. Abbasi, RSC Adv., 2015, 5, 94814.

14 A. Büttner, S. Y. Brauchli, E. C. Constable and C. E. Housecroft, Inorganics, 2018, 6, 40.

15 S. Mathew, A. Yella, P. Gao, R. Humphry-Baker, B. F. E. Curchod, N. Ashari-Astani, I. Tavernelli, U. Rothlisberger, M. K. Nazeeruddin and M. Grätzel, Nat. Chem., 2014, 6, 242.

16 A. Yella, H.-W. Lee, H. N. Tsao, C. Yi, A. K. Chandiran, Md. K. Nazeeruddin, E. W.-G. Diau, C.-Y. Yeh, S. M. Zakeeruddin and M. Graetzel, Science, 2011, 334, 629.

17 M. K. Nazeeruddin, S. M. Zakeeruddin, R. Humphry-Baker, M. Jirousek, P. Liska, N. Vlachopoulos, V. Shklover, C.-H. Fischer and M. Graetzel, Inorg. Chem., 1999, 38, 6298.

18 S. Caramori and C. A. Bignozzi, Recent Developments in the design of dye sensitized solar cell components in Electrochemistry of functional supramolecular systems, J. Wiley \& Sons, 2010, pp. 523-579.

19 M. K. Nazeeruddin, E. Baranoff and M. Grätzel, Sol. Energy, 2011, 85, 1172.

20 P. G. Bomben, B. D. Koivisto and C. P. Berlinguette, Inorg. Chem., 2010, 49, 4960.

21 A. Abbotto, C. Coluccini, E. Dell'Orto, N. Manfredi, V. Trifiletti, M. M. Salamone, R. Ruffo, M. Acciarri, A. Colombo, C. Dragonetti, S. Ordanini, D. Roberto and A. Valore, Dalton Trans., 2012, 41, 11731.

22 C. Dragonetti, A. Valore, A. Colombo, D. Roberto, V. Trifiletti, N. Manfredi, M. M. Salamone, R. Ruffo and A. Abbotto, J. Organomet. Chem., 2012, 714, 88.

23 K. C. D. Robson, B. D. Koivisto and C. P. Berlinguette, Inorg. Chem., 2012, 51, 1501.

24 C. Dragonetti, A. Valore, A. Colombo, M. Magni, P. Mussini, D. Roberto, R. Ugo, A. Valsecchi, V. Trifiletti, N. Manfredi and A. Abbotto, Inorg. Chim. Acta, 2013, 405, 98.

25 C. Dragonetti, A. Colombo, M. Magni, P. Mussini, F. Nisic, D. Roberto, R. Ugo, A. Valore, A. Valsecchi, P. Salvatori, M. G. Lobello and F. De Angelis, Inorg. Chem., 2013, 52, 10723.

26 A. Colombo, C. Dragonetti, M. Magni, D. Meroni, R. Ugo, G. Marotta, M. G. Lobello, P. Salvatori and F. De Angelis, Dalton Trans., 2015, 44, 11788.

27 A. Colombo, C. Dragonetti, A. Valore, C. Coluccini, N. Manfredi and A. Abbotto, Polyhedron, 2014, 82, 50.
28 A. Colombo, C. Dragonetti, D. Roberto, R. Ugo, N. Manfredi, P. Manca, A. Abbotto, G. Della Giustina and G. Brusatin, Inorg. Chim. Acta, 2019, 489, 263.

29 M. Sandroni, M. Kayanuma, A. Planchat, N. Szuwarski, E. Blart, Y. Pellegrin, C. Daniel, M. Boujtita and F. Odobel, Dalton Trans., 2013, 42, 10818.

30 B. Bozic-Weber, E. C. Constable and C. E. Housecroft, Coord. Chem. Rev., 2013, 257, 3089.

31 A. Colombo, C. Dragonetti, D. Roberto, A. Valore, P. Biagini and F. Melchiorre, Inorg. Chim. Acta, 2013, 407, 204.

32 A. Buttner, S. Y. Brauchli, R. Vogt, E. C. Constable and C. E. Housecroft, RSC Adv., 2016, 6, 5205.

33 M. Willgert, A. Boujemaoui, E. Malmstrom, E. C. Constable and C. E. Housecroft, RSC Adv., 2016, 6, 56571.

34 S. O. Furer, L. Y. N. Luu, B. Bozic-Weber, E. C. Constable and C. E. Housecroft, Dyes Pigm., 2016, 132, 72.

35 F. J. Malzner, C. E. Housecroft and E. C. Constable, Inorganics, 2018, 6, 57.

36 W. Sang-Aroon and V. Amornkitbamrung, Walailak J. Sci. \& Tech., 2018, 15, 455.

37 A. Büttner, S. Y. Brauchli, E. C. Constable and C. E. Housecroft, Inorganics, 2018, 6, 40.

38 F. J. Malzner, M. Willgert, E. C. Constable and C. E. Housecroft, J. Mater. Chem. A, 2017, 5, 13717.

39 M. Sandroni, L. Favereau, A. Planchat, H. Akdas-Kilig, N. Szuwaarsky, Y. Pellegrin, E. Blart, H. Le Bozec, M. Boujtita and F. Odobel, J. Mater. Chem. A, 2014, 2, 9944.

40 To compare the photoconversion efficiencies of DSSCs obtained in various laboratories, it is convenient to report not only the absolute efficiency but also that relative to a cell based on N719 dye and $\mathrm{I}^{-} / \mathrm{I}_{3}{ }^{-}$electrolyte set at $100 \%$ measured in the same laboratory, called $\eta_{\text {rel }}$.

41 Important information that should be clearly specified in reporting photoelectrochemical performances of DSSCs is whether the devices were masked or unmasked, with the photocurrents being influenced by this experimental shrewdness. Actually, masking is the best practice and should be adopted always in order to have accurate values of photo-conversion efficiency. See: H. J. Snaith, Energy Environ. Sci., 2012, 5, 6513.

42 L. N. Ashbrook and C. M. Elliott, J. Phys. Chem. C, 2013, 117, 3853.

43 B. Bozic-Weber, E. C. Constable, S. O. Fuerer, C. E. Housecroft, L. J. Troxler and J. A. Zampese, Chem. Commun., 2013, 49, 7222.

44 S. O. Furer, B. Bozic-Weber, T. Schefer, C. Wobill, E. C. Constable, C. E. Housecroft and M. Willgert, J. Mater. Chem. A, 2016, 4, 12995.

45 S. Hattori, Y. Wada, S. Yanagida and S. Fukuzumi, J. Am. Chem. Soc., 2005, 127, 9648.

46 Y. Bai, Q. Yu, N. Cai, Y. Wang, M. Zhang and P. Wang, Chem. Commun., 2011, 47, 4376.

47 A. Colombo, C. Dragonetti, M. Magni, D. Roberto, F. Demartin, S. Caramori and C. A. Bignozzi, ACS Appl. Mater. Interfaces, 2014, 6, 13945. 
48 M. Magni, R. Giannuzzi, A. Colombo, M. P. Cipolla, C. Dragonetti, S. Caramori, S. Carli, R. Grisorio, G. P. Suranna, C. A. Bignozzi, D. Roberto and M. Manca, Inorg. Chem., 2016, 55, 5245.

49 M. Freitag, F. Giordano, W. Yang, M. Pazoki, Y. Hao, B. Zietz, M. Grätzel, A. Hagfeldt and G. Boschloo, J. Phys. Chem. C, 2016, 120, 9595.

50 A. Colombo, G. Di Carlo, C. Dragonetti, M. Magni, A. Orbelli Biroli, M. Pizzotti, D. Roberto, F. Tessore, E. Benazzi, C. A. Bignozzi, L. Casarin and S. Caramori, Inorg. Chem., 2017, 56, 14189.

51 M. Magni, A. Colombo, C. Dragonetti and P. Mussini, Electrochim. Acta, 2014, 141, 324.

52 E. Benazzi, M. Magni, A. Colombo, C. Dragonetti, S. Caramori, C. A. Bignozzi, R. Grisorio, G. P. Suranna, M. P. Cipolla, M. Manca and D. Roberto, Electrochim. Acta, 2018, 271, 180.

53 A. Colombo, R. Ossola, M. Magni, D. Roberto, D. Jacquemin, C. Castellano, F. Demartin and C. Dragonetti, Dalton Trans., 2018, 47, 1018.

54 C. Dragonetti, M. Magni, A. Colombo, F. Melchiorre, P. Biagini and D. Roberto, ACS Appl. Energy Mater., 2018, 1, 751.

55 M. Karpacheva, F. J. Malzner, C. Wobill, A. Büttner, E. C. Constable and C. E. Housecroft, Dyes Pigm., 2018, 156, 410.

56 C. Dragonetti, M. Magni, A. Colombo, F. Fagnani, D. Roberto, F. Melchiorre, P. Biagini and S. Fantacci, Dalton Trans., 2019, DOI: 10.1039/C9DT00790C.
57 M. Schmittel and A. Ganz, Chem. Commun., 1997, 19.

$58 \mathrm{Cu}$ (I)/(II) couples are usually characterized by slow electrontransfer processes and rapid non-radiative decay of the metal-to-ligand charge transfer excited state with diminution of the excited-state lifetime of the cuprous complex, due to a significant change in the preferred coordination geometry from tetrahedral $\mathrm{Cu}(\mathrm{I})$ to tetragonal $\mathrm{Cu}(\mathrm{II})$; in order to prevent geometric changes and optimize the electron-transfer properties, the coordination sphere of the copper complex has to be rationally designed, with suitable sterically hindered groups adjacent to the donor nitrogen atoms of the ligands. See: N. Robertson, ChemSusChem, 2008, 1, 977.

59 Y. Saygili, M. Söderberg, N. Pellet, F. Giordano, Y. Cao, A. Belen Muñoz-García, S. M. Zakeeruddin, N. Vlachopoulos, M. Pavone, G. Boschloo, L. Kavan, J.-E. Moser, M. Grätzel, A. Hagfeldt and M. Freitag, J. Am. Chem. Soc., 2016, 138, 15087.

60 L. Kavan, H. Krysova, P. Janda, H. Tarabkova, Y. Saygilic, M. Freitag, S. M. Zakeeruddin, A. Hagfeld and M. Grätzel, Electrochim. Acta, 2017, 251, 167.

61 P. Ferdowski, Y. Saygili, S. M. Zakeeruddin, J. Mokhtari, M. Graetzel, A. Hagfeldt and L. Kavan, Electrochim. Acta, 2018, 265, 194.

62 Y. Saygili, M. Stojanovic, H. Michaels, J. Tiepelt, J. Teuscher, A. Massaro, M. Pavone, F. Giordano, S. M. Zakeeruddin, G. Boschloo, J.-E. Moser, M. Grätzel, A. B. Muñoz-García, A. Hagfeldt and M. Freitag, ACS Appl. Energy Mater., 2018, 1, 4950. 